\title{
Biogenic Uraninite Nanoparticles and Their Importance for Uranium Remediation
}

1811-5209/08/0004-0407\$2.50 DOI: $10.2113 /$ gselements.4.6.407

B complexities of this important natural nanomaterial. Intriguingly, in spite of its 20 incredibly diminutive size, the molecular-scale structure, energetics, and surfacearea-normalized dissolution rates of hydrated biogenic uraninite appear to be similar to those of coarser-particle, abiotic, stoichiometric $\mathrm{UO}_{2}$. These findings have important implications for the role of size as a moderator of nanoparticle aqueous reactivity and for the bioremediation of subsurface $U(V I)$ contamination. iogenic uraninite is of interest to geoscientists for its importance to bioremediation strategies, remarkably small particle size, and biological origin. Recent studies have begun to illuminate the chemical/structural

KEYWORDS: uraninite, biogenic uraninite, microbial uranium reduction, bioremediation, dissolution, EXAFS

\section{INTRODUCTION}

Biogenic uraninite is a fascinating and important nanoscale biogeological material. Its properties, particularly solubility and dissolution kinetics, are crucial to the viability of microbial bioremediation strategies that seek to mitigate subsurface uranium contamination via stimulated uranium reduction. Such approaches typically utilize electron donors such as ethanol or acetate to establish anoxia in an aquifer (by injection), which is followed by microbial reduction of electron acceptors such as $\mathrm{NO}_{3}{ }^{-}, \mathrm{U}(\mathrm{VI}), \mathrm{Fe}(\mathrm{III})$, and $\mathrm{SO}_{4}{ }^{2-}$. Microbially mediated in situ U(VI) reduction is currently being investigated in field-scale tests at a number of contaminated U.S. Department of Energy nuclear legacy sites (FIG. 1) and thus far has produced promising results (Wu et al. 2007; Yabusaki et al. 2007). Uraninite is the most desirable product of in situ stimulated microbial reduction of subsurface $\mathrm{U}(\mathrm{VI})$ because it is orders of magnitude less soluble than most other $\mathrm{U}$ species.

The geochemical behavior of biogenic uraninite has been thought to be strongly influenced by its diminutive size (typically 2 to $3 \mathrm{~nm}$ diameter). In particular, nanoscale size has been proposed to chemically destabilize the product-a

1 Stanford Synchrotron Radiation Laboratory 2575 Sand Hill Road, MS 69, Menlo Park, CA 94025, USA E-mail: bargar@slac.stanford.edu

2 Environmental Microbiology Laboratory, Ecole Polytechnique Fédérale de Lausanne, 1015 Lausanne, Switzerland E-mail: rizlan.bernier-latmani@epfl.ch

3 Department of Energy, Environmental and Chemical Engineering Washington University, 1 Brookings Drive

Campus Box 1180, St. Louis, MO 63130, USA

E-mail: giammar@wustl.edu

4 Division of Environmental and Biomolecular Systems Oregon Health \& Science University, 20000 NW Walker Rd. Beaverton, OR 97006, USA

E-mail: tebo@ebs.ogi.edu reasonable hypothesis considering that ca $50 \%$ of all atoms reside at the oxide-water interface or in the subjacent polyhedral layer (Banfield and Zhang 2001; Gilbert and Banfield 2005). Surface energy-driven enhancement of the solubility of uraninite nanoparticles, if it were significant (Suzuki et al. 2002), could render the biogenic product inadequate as a sink phase for subsurface uranium, even under anoxic conditions. Thus, nanosize is brought sharply into focus as a potentially important moderator of reactivity and, consequently, of remediation design, cost, and performance.

Further enriching this subject are the biological origin and variable structural chemistry of uraninite. It is likely that mechanisms specific to enzymatically mediated synthesis routes provide unique controls on the structure, composition, and reactivity of biogenic uraninite. Moreover, the propensity of uraninite to incorporate impurities is known to profoundly influence its geochemical stability.

In concert, the above-mentioned factors-size, structure, composition, and biology-suggest a complex mineralogy and variable reactivity for biogenic uraninite. This paper reviews current knowledge of these fundamental factors and their implications for the geochemical behavior of biogenic nano-uraninite in the subsurface. Recent studies have begun to illuminate this subject and are leading to some unanticipated discoveries.

\section{STRUCTURE AND COMPOSITION OF GEOLOGICAL URANINITE}

The term uraninite is used to denote compositionally complex, nonstoichiometric, and generally cation-substituted forms of $\mathrm{UO}_{2}$ observed in nature (Janeczek and Ewing 1992). Uraninite exhibits a rich structural chemistry, which derives its properties from its open fluorite structure. In particular, half of the cubically coordinated interstitial sites in the unit cell are vacant (the other half being occupied by $U$ atoms) and thus provide conduits and resting sites for excess oxygen atoms, which readily enter the structure (Allen and Tempest 1986). Indeed, pure $\mathrm{UO}_{2.0}$ is not observed in nature and is difficult to produce synthetically. More commonly, the composition $\mathrm{UO}_{2+x}$ is observed, with $x$ exhibiting values as high as 0.25 (i.e. $\mathrm{U}_{4} \mathrm{O}_{9}$ ) in sedimentary geological settings (Finch and Murakami 1999). As $x$ increases, the $\mathrm{UO}_{2+x}$ oxygen sublattice becomes increasingly distorted around the $U$ atom positions (but the $U$ sublattice is preserved) (Conradson et al. 2004), accompanied by a 

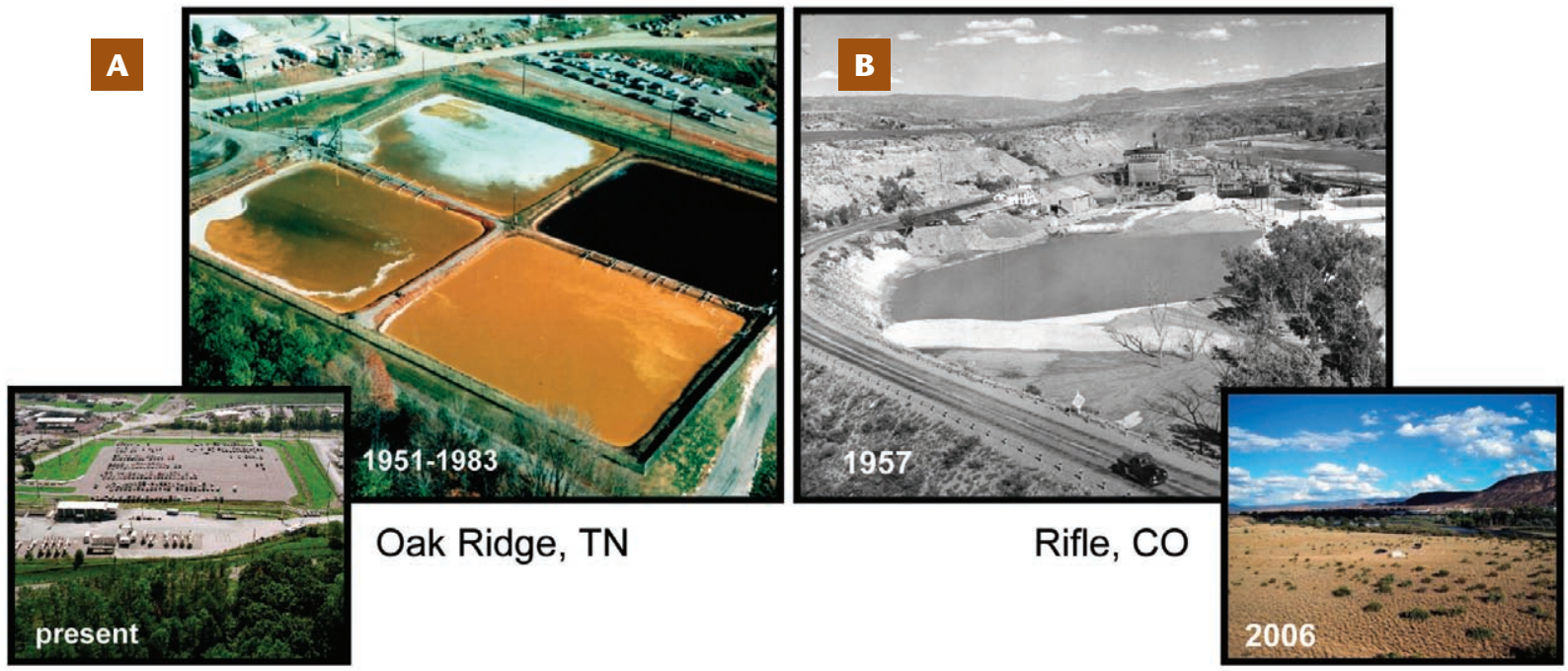
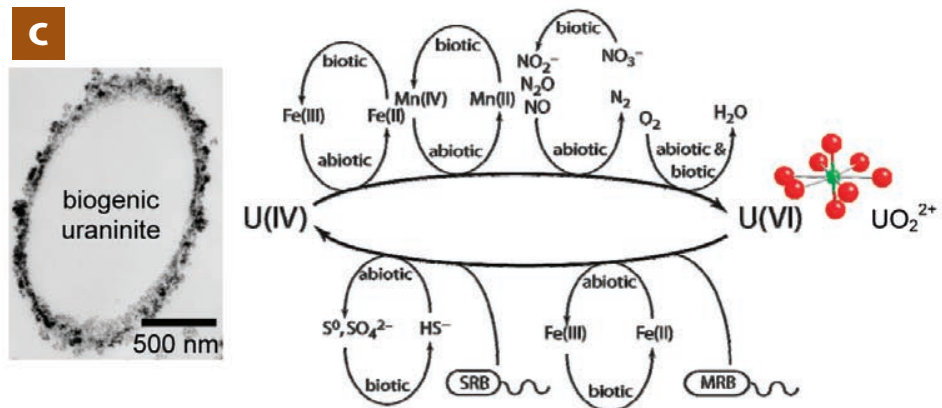

D

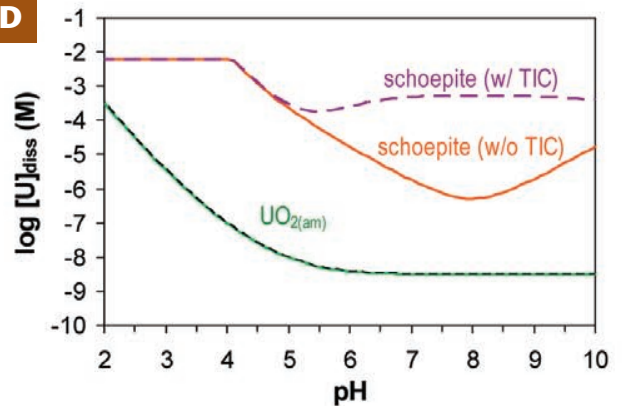

90

95

100

in groundwater (Finch and Ewing 1992; Shoesmith 2000). This prediction is of considerable practical significance to uranium bioremediation and warrants further investigation.

\section{BIOLOGICAL REDUCTION AND URANINITE PRECIPITATION}

Microbial U(VI) reduction has been shown to be catalyzed by many microorganisms, the majority being either metalor sulfate-reducing bacteria (Wall and Krumholz 2006). Few studies are able to couple this process to growth, suggesting that microbial $\mathrm{U}(\mathrm{VI})$ reduction is predominantly a fortuitous process by which microbial enzymes transfer excess electrons to $\mathrm{U}(\mathrm{VI})$.

The first step in biogenic uraninite formation is the reduction of $U(V I)$ to $U(I V)$. Electron transfer is presumed to be mediated by c-type cytochromes localized either in the periplasm or on the outer membrane (Wall and Krumholz 2006). However, the mechanism by which these cytochromes transfer electrons to $\mathrm{U}(\mathrm{VI})$ is unknown. $\mathrm{U}(\mathrm{V})$ is unstable as an aqueous complex (Nagaishi et al. 1996), and it is therefore possible that enzymatic reduction proceeds from $\mathrm{U}(\mathrm{VI})$ to $\mathrm{U}(\mathrm{V})$, followed by disproportionation to $\mathrm{U}(\mathrm{IV})$ and U(VI). Tentative evidence in support of this mechanism has been provided by Renshaw et al. (2005) and Grossmann et al. (2007), but further work is required to unambiguously demonstrate the relevance of this reduction pathway.

After $U(V I)$ reduction to $U(I V)$, the second step in biogenic uraninite formation entails the precipitation of the mineral. It is generally believed that uraninite precipitates near the site of $\mathrm{U}(\mathrm{VI})$ reduction. For most Gram-negative bacteria, biogenic uraninite is localized in the periplasmic space and extracellularly (Wall and Krumholz 2006). It is conceivable that complexed U(IV) or nanoparticulate uraninite could the abundance of calcium in groundwater. Positive $c$ possibly by higher-valent uranium defects. An inclusive structural formula for uraninite has been proposed as $\left(\mathrm{U}^{4+}{ }_{1-x-y-z-v} \mathrm{U}^{6+}{ }_{x} \mathrm{REE}^{3+}{ }_{y} \mathrm{M}^{2+}{ }_{y}{ }^{4-}{ }_{v}\right) \mathrm{O}_{2+x-(0.5 y)-z-2 v}$, where "? " denotes an oxygen-vacancy pair (Janeczek and Ewing 1992). Notably, natural uraninite is stable at redox conditions at which stoichiometric $\mathrm{UO}_{2}$ corrodes. It thus can be concluded that impurity ions and hyperstoichiometry should enhance the stability of biogenic uraninite with respect to oxidation 
diffuse out of the periplasm following reduction. Further, a study of the relative localization of uraninite nanoparticles and c-type cytochromes showed their close extracellular association in a matrix of exopolymeric substances (EPS) (Marshall et al. 2006). A separate study demonstrated the strong binding of a cytochrome $c_{3}$ to uraninite (Payne et al. 2004). These two studies support the hypothesis that precipitation occurs in the vicinity of the site of reduction. The association of biogenic uraninite with proteins and EPS is likely to prevent its colloidal transport despite its very small size.

\section{STRUCTURE AND COMPOSITION OF BIOGENIC URANINITE}

The formation of uraninite by microbial U(VI) reduction was first demonstrated using the iron-reducing bacterium Geobacter metallireducens strain GS15 (Gorby and Lovley 1992). Suzuki et al. (2002) reported that biogenic uraninite produced by mixed bacterial cultures in natural sediments and pure cultures of Desulfosporosinus spp. was comprised of nanoparticles with diameters of $<3 \mathrm{~nm}$. Extended X-ray absorption fine structure (EXAFS) spectroscopy measurements indicated that the average distance from individual $\mathrm{U}$ atoms to the next-closest $\mathrm{U}$ neighbor $(3.80 \AA$ ) was diminished as compared to bulk $\mathrm{UO}_{2}(3.87 \AA)$, from which it was inferred that the uraninite lattice was contracted. The use of short-range structure, such as the first U neighbor distances, to assess long-range (i.e. unit-cell) structure can be complicated by local disorder, such as particle surface relaxation, and hence the conclusions may contain significant uncertainties. The potential for lattice strain bears attention, however, as it would imply elevated total energy, and hence elevated solubility (Suzuki et al. 2002) and decreased stability.

Subsequent studies have also reported biogenic uraninite particle sizes in the 2 to $10 \mathrm{~nm}$ range and slight but significant contraction of the first U-U shell (Renshaw et al. 2005; Singer et al. 2006; Senko et al. 2007; Burgos et al. 2008; Komlos et al. 2008). Similar results have been reported for uraninite nanoparticles produced by abiotic reduction of $\mathrm{U}(\mathrm{VI})$ by green rust (O'Loughlin et al. 2003). Stoichiometry and unit-cell structure were not directly addressed in these studies. In the case where a single $U$ phase was likely to have been dominant (Singer et al. 2006), the EXAFS results suggest a single $\mathrm{U}-\mathrm{O}$ shell, which is consistent with compositions below $\sim \mathrm{UO}_{2.05}$.

The unit-cell structure of hydrated, washed, biogenic uraninite produced by Shewanella oneidensis strain MR-1 was recently quantified using in situ synchrotron-based powder diffraction (SR-PD) (Schofield et al. 2008). This study revealed that the lattice constant for biogenic uraninite was similar to that of bulk stoichiometric $\mathrm{UO}_{2.00}$ (5.467[4] vs $5.468 \AA$ ) , indicating that the biogenic uraninite lattice was largely unstrained. The mean particle size for the biogenic uraninite produced in this study was $2.5 \mathrm{~nm}$. The previously observed foreshortening of first U-U shell distances is therefore best ascribed to contraction of the structure in immediate proximity to the particle surfaces. Extended-range EXAFS results (Schofield et al. 2008) showed the cores of biogenic uraninite particles to be highly ordered, as indicated by the presence of significant Fourier transform peaks at U-U distances greater than $4 \AA$ (FIG. 2). The particle cores were found to have an overall diameter of ca $1.3 \mathrm{~nm}$, to be structurally similar to stoichiometric $\mathrm{UO}_{2.0}$, and to be surrounded by a slightly distorted but still crystalline outer region. Studies of biogenic uraninite obtained from Geobacter, Anaerobyxobacter, and Desulfovibrio species under similar conditions show similar ordering of nanoparticle cores (unpublished results). The apparently low value of $x$ in the formula $\mathrm{UO}_{2+x}$ for the biogenic urani- nite, as revealed by both SR-PD and EXAFS, may result from the biological mechanism of reduction, in which pure $\mathrm{U}(\mathrm{IV})$ is produced and subsequently precipitated near enzyme sites, leaving little opportunity for the incorporation of higher-valence $\mathrm{U}$.

The absence of lattice strain and similarity to stoichiometric $\mathrm{UO}_{2}$ suggest that the thermodynamic properties of $\mathrm{UO}_{2}$ should approximate those of biogenic uraninite that has not acquired cation impurities. While these conclusions represent a significant step forward, they neglect the potentially important roles of natural impurities that are likely to be present in biogenic uraninite. As noted above, structural impurities are likely to enhance the subsurface stability of uraninite. The ability of biogenic uraninite to acquire impurities is, however, likely to be mediated by the ability of specific foreign cations to adsorb to growing crystal faces (Erwin et al. 2005). Hence natural doping of uraninite nanoparticles may not be significant for all potential dopants. Moreover, the molecular-scale structural mechanisms by which impurities are retained in geological uraninite have not been fully established. Investigations that address the structural chemistry of impurities in biogenic uraninite and their impact on stability are therefore needed.

\section{FACTORS AFFECTING THE REACTIVITY OF ABIOTIC AND BIOGENIC URANINITE}

\section{Solubility and Dissolution Rates of Abiotic UO2 Analogs}

The equilibrium solubility of U(IV) oxides varies according to $\mathrm{pH}$, the degree of crystallinity, the presence of oxidized surface layers (Rai et al. 1990), and possibly particle size. The solubility of $\mathrm{UO}_{2}$ colloids at $\mathrm{pH} \sim 1$ is reportedly greater than that of bulk $\mathrm{UO}_{2}$ (Opel et al. 2007), but reliable solubility data at near-neutral $\mathrm{pH}$ are not available for $\mathrm{UO}_{2}$ at such particles sizes.

The dissolution rate of $\mathrm{UO}_{2}$ is strongly influenced by $\mathrm{pH}$ (faster at low $\mathrm{pH}$ ), solution composition, and in particular the concentrations of oxidants and complexing ligands. Kinetic models for the oxidative dissolution of $\mathrm{UO}_{2}$ include steps for the surface oxidation of $U(I V)$, possible production of U(V) (Santos et al. 2005), and subsequent release of U(VI) (Shoesmith 2000; Bruno and Ewing 2006). Dissolution rates are orders of magnitude faster in the presence of oxygen than under reducing conditions. $\mathrm{UO}_{2}$ dissolution is dramatically accelerated by species that complex U(VI), the product of oxidation. Carbonate is the most important complexant in most natural environments, and its concentration can increase as a result of stimulated microbial respiration. In the absence of sufficient carbonate, corrosion products may accumulate as secondary $\mathrm{U}(\mathrm{VI})$ precipitates that form on $\mathrm{UO}_{2}$ surfaces (Finch and Murakami 1999; Shoesmith 2000; Bruno and Ewing 2006).

\section{Dissolution Rates of Biogenic Uraninite}

The long-term stability of biogenic uraninite in the subsurface will depend on the rates of oxidation and dissolution reactions. Laboratory and field studies have observed the oxidation of U(IV), likely representing different mixtures of uraninite and U(IV) adsorbed on biomass, on timescales from hours to several months (Moon et al. 2007; Senko et al. 2007; Wu et al. 2007; Komlos et al. 2008). Oxidation rates increase with decreasing particle size and decreasing degree of aggregation. These effects may be qualitatively explained by the inferred decreasing effective specific surface area $\left(\mathrm{m}^{2} / \mathrm{g}\right)$ of the particles and aggregates (Senko et al. 2007). In order to establish the effect of particle size on the intrinsic energetics and oxidation rates of the nanoparticles, direct measurements of surface areas, which are 

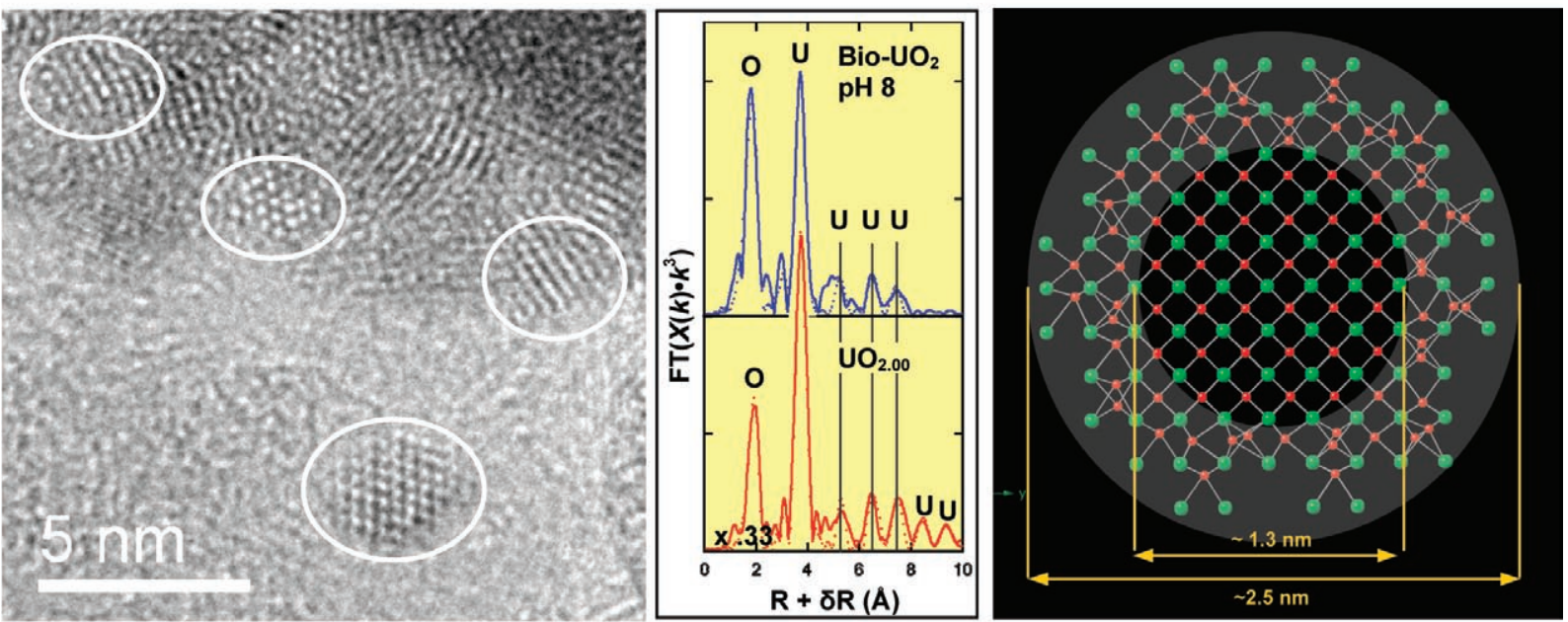

FigurE 2 Left: Fourier-filtered HR-TEM image of biogenic uraninite produced by Shewanella oneidensis strain MR-1, showing $\mathrm{UO}_{2}$ lattice fringes. Ovals indicate individual nanoparticles. Center: Fourier transforms (FT) of EXAFS spectra from biogenic uraninite and stoichiometric $\mathrm{UO}_{2}$ (solid lines are data; dotted lines are fits). Right Ball-and-stick representation of the structure of biogenic uraninite nanoparticles, from Schofield et al. (2008). Uranium atoms are red; oxygen atoms are green. The shaded area emphasizes the slightly distorted outer zone of the nanoparticles. The contraction in the first $\mathrm{U}$ neighbor distance, believed to occur at the immediate periphery of the particles, is illustrated with exaggerated atomic displacements. difficult to accurately establish from TEM measurements, are required (Senko et al. 2007). More-comprehensive, quantitative models of the rates and mechanisms of biogenic uraninite dissolution are needed for assessing its fate in the subsurface.

Quantitative measurements of the dissolution rates and equilibrium solubility of biogenic uraninite under controlled $\mathrm{pH}$, oxygen pressure, and total inorganic carbon (TIC) conditions using continuous-flow, stirred-tank reactors have been performed recently using a well-characterized biogenic uraninite produced by Shewanella oneidensis MR-1 (Ulrich et al. 2008). Under reducing, near-neutral-pH conditions (no carbonate), nanocrystalline biogenic uraninite dissolved slowly. As determined from the results of continuous-flow dissolution reactor experiments (FIG. $3 \mathrm{~A}$ ), the biogenic uraninite exhibited area-normalized rates in the range of $1.1 \times 10^{-14}$ to $3.4 \times 10^{-13} \mathrm{~mol} \mathrm{~m}-2 \mathrm{~s}-1$, which are of the same order of magnitude as those of a coarser-grained synthetic $\mathrm{UO}_{2}$. With a size of $92-200 \mathrm{~nm}$, the blocky, prismatic, abiotically synthesized $\mathrm{UO}_{2}$ particles were much larger than the biogenic uraninite particles. The equilibrium solubilities of the biogenic and synthetic $\mathrm{UO}_{2}$ materials were also comparable. These observations demonstrate that the nanocrystalline nature of the biogenic uraninite did not render it inherently less stable than bulk $\mathrm{UO}_{2}$. This conclusion is consistent with the structural similarity of biogenic uraninite to stoichiometric $\mathrm{UO}_{2.0}$.

The addition of $1 \mathrm{mM}$ dissolved inorganic carbon while maintaining anoxic conditions increased the dissolution rates of biogenic uraninite and stoichiometric $\mathrm{UO}_{2}$ by more than an order of magnitude (FIG. 3B). The enhancement was greater for the biogenic uraninite, suggesting that particle size may impact surface-mediated processes. Carbonate forms strong complexes with U(VI), whereas it does not with $\mathrm{U}(\mathrm{IV})$. This observation suggests that the surface has been oxidized to U(VI) under reducing conditions, as previously observed (Bruno et al. 1991), and that the detachment of $\mathrm{U}(\mathrm{VI})$ from the surface is the rate-limiting step in biogenic uraninite dissolution in the absence of carbonate.

\section{Biogeochemical Processes Influencing Biogenic Uraninite Stability}

Microbial activity can either prolong or diminish the longevity of subsurface biogenic uraninite through indirect or direct processes involving linked geochemical cycles and is thus important to understand. Fe(II)/Mn(II)-oxidizing and denitrifying microorganisms whose activity leads to the formation of Fe(III) and Mn(III,IV) (hydr)oxides or nitrite and other nitrogen-bearing intermediates have the potential to indirectly catalyze uraninite oxidation. Fredrickson et al. (2002) showed that synthetic and biogenic Mn oxides oxidize extracellular $\mathrm{UO}_{2}$ produced by Shewanella putrefaciens but do not affect periplasmic $\mathrm{UO}_{2}$. The iron oxide ferrihydrite was found to be responsible for the oxidation of biogenic $\mathrm{UO}_{2}$ in an abiotic, anaerobic system (Ginder-Vogel et al. 2006). Push-pull field experiments (Senko et al. 2002) unveiled a link between nitrate addition and uranium solubilization due to the abiotic oxidation of U(IV) by intermediates of microbial nitrate reduction, specifically nitrite. Such processes are expected to compromise the effectiveness of microbial bioremediation strategies. However, the opposite effect, i.e. the enhancement of bioremediation effectiveness, may occur if sulfate-reducing bacteria produce sulfide minerals that can locally buffer the oxidation-reduction potential of groundwater and protect uraninite from oxidation. Such a mechanism has been implicated from laboratory column experiments (Abdelouas et al. 1999). Similarly, in sediments from an open-pit mine, the majority of $U$ was found to remain as $\mathrm{U}(\mathrm{IV})$ despite seasonal exposure to air. The stability of reduced $U$ was attributed to the presence of organic matter and sulfide minerals (Suzuki et al. 2005).

There is evidence that bacteria can directly oxidize U(IV) under anaerobic conditions and at near-neutral $\mathrm{pH}$. Thiobacillus denitrificans has been shown to be capable of nitrate-dependent $\mathrm{UO}_{2}$ oxidation (Beller 2005). Nitrategrown Geobacter metallireducens was reported to directly oxidize $\mathrm{U}(\mathrm{IV})$ present as soluble $\mathrm{UBr}_{4}$ with nitrate as an electron acceptor (Finneran et al. 2002). Finally, under acidic and aerobic conditions, the acidophilic bacterium Acidithiobacillus ferrooxidans was found to grow by fixing $\mathrm{CO}_{2}$ and using $\mathrm{U}^{4+}$ as an electron donor at $\mathrm{pH} 1.5$ (DiSpirito and Tuovinen 1982). Further studies of both direct and indirect oxidation processes are needed to assess their roles in the field. 

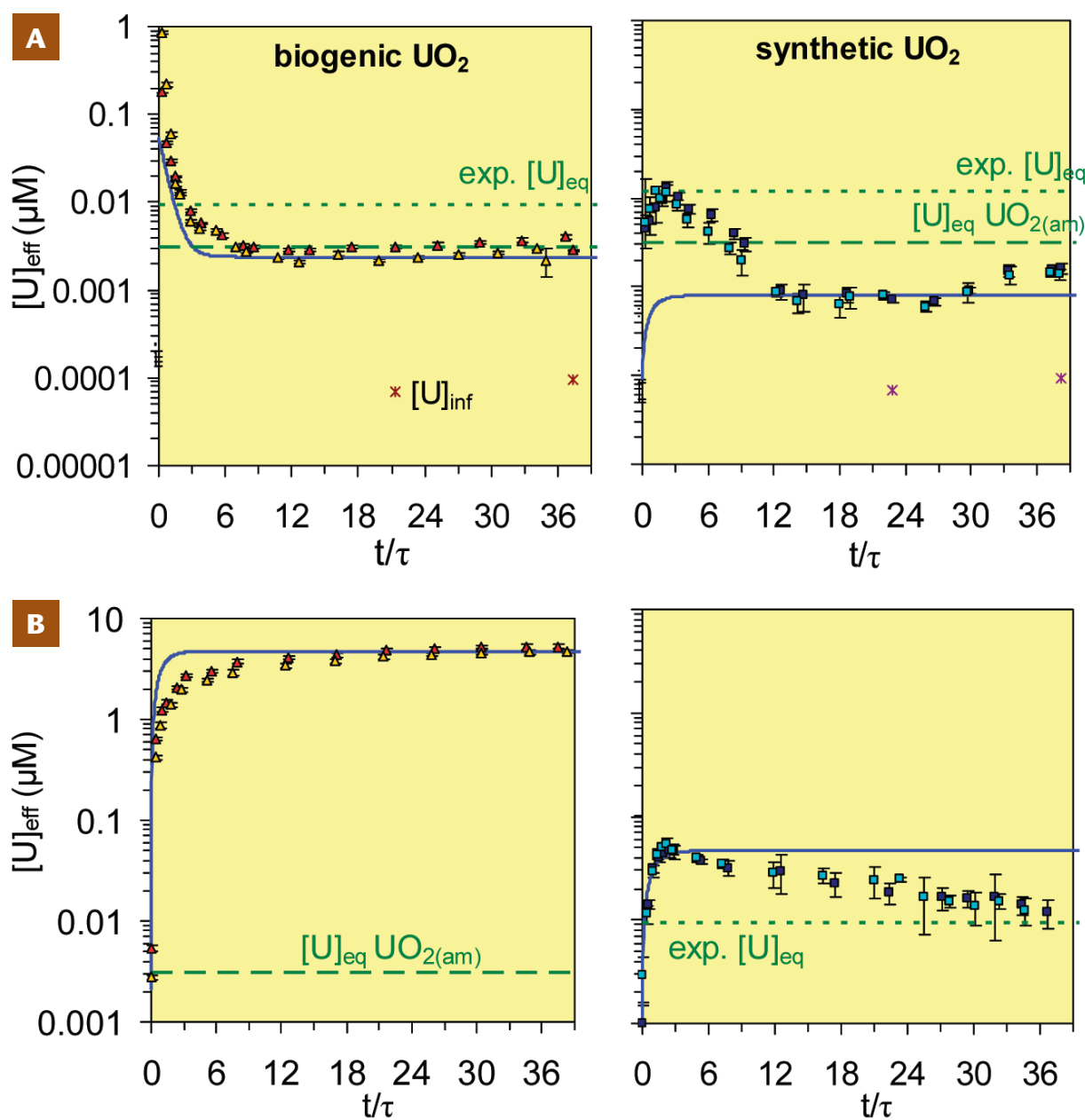

Dissolution of biogenic uraninite and abiotically synthesized uraninite under reducing conditions that are (A) carbonate-free $(\mathrm{pH} 7.5 \pm 0.2)$ and (B) contain $1 \mathrm{mM}$ dissolved inorganic carbon $(\mathrm{pH} 8.1 \pm 0.3)$. Dissolved $U,[U]_{\text {eff, }}$ from two replicate reactors is shown as a function of normalized time, which is the cumulative reaction time ( $\mathrm{t}$ ) divided by the reactor hydraulic residence time ( $\sim 6$ minutes). The dotted and dashed lines indicate the equilibrium concentration determined experimentally (exp. [U] eq) and calculated ([U] $\left.]_{\text {eq }} \cup_{2(\text { am) }}\right)$ from the thermodynamics of $\mathrm{UO}_{2(\mathrm{am}),}$ respectively. The solid line illustrates the predicted response to the initial $\mathrm{U}$ load assuming dissolution rate constants for biogenic $\mathrm{UO}_{2}$ of $5.5 \times 10^{-13}$ and $1.75 \times 10^{-10}$ and for synthetic $\mathrm{UO}_{2}$ of $3.3 \times 10^{-13}$ and $2.7 \times 10^{-11} \mathrm{~mol} \mathrm{U} \mathrm{m}^{-2} \mathrm{~s}^{-1}$. [U] $]_{\text {inf }}$ is the influent $\mathrm{U}$ concentration. Figure adapted from Ulrich et al. (2008)

\section{CONCLUSIONS AND IMPLICATIONS FOR URANIUM FATE AND TRANSPORT FOLLOWING IN SITU BIOREMEDIATION}

Successful uranium bioremediation is likely to require continued maintenance of strictly anaerobic conditions. As long as transport-limited removal of reaction products allows approach to equilibrium, particle size is anticipated to minimally impact the stability of biogenic uraninite. Moreover, it is likely that acquisition of impurity cations from groundwater and excess structural oxygens may significantly enhance the stability of uraninite with respect to oxidation by $\mathrm{O}_{2}$. Although diminutive, the nanoparticles are closely associated with biomass and tend to aggregate, making it unlikely that they will be transported by advection in groundwater.
Distortion of nanoparticle surface structure is a means by which surface energy can be mitigated (Banfield and Zhang 2001). It also has been noted that hydration (Navrotsky et al. 2008) and aggregation (Huang et al. 2004) play important roles in reducing nanoparticle surface energy and extending the stability range of the most stable largecrystal phase. It is plausible that each of these effects acts to mitigate the impact of particle size on the observed stability of biogenic uraninite.

The intrinsically faster carbonate-enhanced dissolution of biogenic uraninite relative to coarse-grained abiotic $\mathrm{UO}_{20}$ suggests that the interfacial chemistry of biogenic uraninite is different from that of larger-particle forms. These differences are likely to be problematic for predicting rates of uranium release in the field. Research that improves our understanding of the fundamental factors governing the surface chemistry of nanoparticulate uraninite is therefore important for constructing accurate geochemical models of uranium behavior following bioremediation. These challenges will present opportunities for research in nano(bio) geoscience for some time to come.

\section{ACKNOWLEDGEMENTS}

The authors are grateful for funding from the U.S. Department of Energy (DOE), Office of Biological and Environmental Research, grant DE-FG02-06ER64227 (linked project numbers SCW0041, 1027833, 1027834, and 1027837), from the DOE Office of Basic Energy Sciences, which supports the Stanford Synchrotron Radiation Laboratory, and from the Swiss National Science Foundation (grant 20021-113784). 


\section{REFERENCES}

Abdelouas A, Lutze W, Nuttall HE (1999) Oxidative dissolution of uraninite precipitated on Navajo Sandstone. Journal of Contaminant Hydrology 36: 353-375

Allen GC, Tempest PA (1986) Ordered defects in the oxides of uranium. Proceedings of the Royal Society of London Series A 406: $325-344$

Banfield JF, Zhang H (2001) Nanoparticles in the Environment. In: Banfield JF, Navrotsky A (eds) Nanoparticles and the Environment. Reviews in Mineralogy \& Geochemistry 44, Mineralogical Society of America, Chantilly, VA, pp. 1-58

Beller HR (2005) Anaerobic, nitrate-dependent oxidation of U(IV) oxide minerals by the chemolithoautotrophic bacterium Thiobacillus denitrificans. Applied and Environmental Microbiology 71: 2170-2174

Bruno J, Casas I, Puigdomènech (1991) The kinetics of dissolution of $\mathrm{UO}_{2}$ under reducing conditions and the influence of an oxidized surface layer $\left(\mathrm{UO}_{2+\mathrm{x}}\right)$ : Application of a continuous flow-through reactor. Geochimica et Cosmochimica Acta 55: 647-658

Bruno J, Ewing RC (2006) Spent nuclear fuel. Elements 2: 343-349

Burgos WD, McDonough JT, Senko JM, Zhang G, Dohnalkova AC, Kelly SD, Gorby Y, Kemner KM (2008) Characterization of uraninite nanoparticles produced by Shewanella oneidensis MR-1. Geochimica et Cosmochimica Acta 72: 4901-4915

Conradson SD, Manara D, Wastin F, Clark DL, Lander GH, Morales LA, Rebizant J, Rondinella VV (2004) Local structure and charge distribution in the $\mathrm{UO}_{2}-\mathrm{U}_{4} \mathrm{O}_{9}$ system. Inorganic Chemistry 43: 6922-6935

DiSpirito AA, Tuovinen OH (1982) Kinetics of uranous ion and ferrous iron oxidation by Thiobacillus ferrooxidans. Archives of Microbiology 133: 33-37

Erwin SC, Zu L, Haftel MI, Efros AL Kennedy TA, Norris DJ (2005) Doping semiconductor nanocrystals. Nature 436: $91-94$

Finch R, Murakami T (1999) Systematics and paragenesis of uranium minerals. In: Burns PC, Finch RJ (eds) Uranium Mineralogy, Geochemistry and the Environment. Reviews in Mineralogy 38, Mineralogical Society of America, Chantilly, VA, pp. 89-179

Finch RJ, Ewing RC (1992) The corrosion of uraninite under oxidizing conditions. Journal of Nuclear Materials 190: 133-156

Finneran KT, Housewright ME, Lovley DR (2002) Multiple influences of nitrate on uranium solubility during bioremediation of uranium-contaminated subsurface sediments. Environmental Microbiology 4: $510-516$

Fredrickson JK, Zachara JM, Kennedy DW, Liu C, Duff MC, Hunter DB, Dohnalkona A (2002) Influence of Mn oxides on the reduction of $\mathrm{U}(\mathrm{VI})$ by the metal-reducing bacterium Shewanella putrefaciens. Geochimica et Cosmochimica Acta 66: 3247-3262

Gilbert B, Banfield JF (2005) Molecular scale processes involving nanoparticulate minerals in biogeochemical systems. In: Banfield JF, Cervini-Silva J, Nealson KH (eds) Molecular Geobiology. Reviews in Mineralogy and Geochemistry 59, Mineralogical Society of America, Chantilly, VA, pp. 109-156
Ginder-Vogel M, Criddle CS, Fendorf S (2006) Thermodynamic constraints on the oxidation of biogenic $\mathrm{UO}_{2}$ by $\mathrm{Fe}$ (III) (hydr)oxides. Environmental Science \& Technology 40: 3544-3550

Gorby YA, Lovley DR (1992) Enzymatic uranium precipitation. Environmental Science \& Technology 26: 205-207

Grossmann K, Arnold T, Krawczyk-Bärsch E, Diessner S, Wobus A, Bernhard G Krawietz R (2007) Identification of fluorescent $\mathrm{U}(\mathrm{V})$ and $\mathrm{U}(\mathrm{VI})$ microparticles in a multispecies biofilm by confocal laser scanning microscopy and fluorescence spectroscopy. Environmental Science \& Technology 41: 6498-6504

Huang F, Gilbert B, Zhang H, Banfield JF (2004) Reversible, surface-controlled structure transformation in nanoparticles induced by an aggregation state. Physical Review Letters 92: 155501

Janeczek J (1999) Mineralogy and geochemistry of natural fission reactors in Gabon. In: Burns PC, Finch RJ (eds) Uranium: Mineralogy, Geochemistry and the Environment. Reviews in Mineralogy 38, Mineralogical Society of America, Chantilly, VA, pp 321-392

Janeczek J, Ewing RC (1992) Structural formula of uraninite. Journal of Nuclear Materials 190: 128-132

Komlos J, Mishra B, Lanzirotti A, Myneni SCB, Jaffé PR (2008) Real-time speciation of uranium during active bioremediation and U(IV) reoxidation. Journal of Environmental Engineering 134: 78-86

Marshall MJ and 17 coauthors (2006) c-type cytochrome-dependent formation of U(IV) nanoparticles by Shewanella oneidensis. PLoS biology 4: 1324-1333

Moon HS, Komlos J, Jaffé PR (2007) Uranium reoxidation in previously bioreduced sediment by dissolved oxygen and nitrate. Environmental Science \& Technology 41: 4587-4592

Nagaishi R, Katsumura Y, Ishigure K, Aoyagi H, Yoshida Z, Kimura T (1996) Photoreduction of uranyl ion in aqueous solution. I. With ethanol in sulphuric acid solutions. Journal of Photochemistry and Photobiology A 96: 45-50

Navrotsky A, Mazeina L, Majzlan J (2008) Size-driven structural and thermodynamic complexity in iron oxides. Science 319: 1635-1638

O'Loughlin EJ, Kelly SD, Cook RE, Csencsits R, Kemner KM (2003) Reduction of uranium(VI) by mixed iron(II)/iron(III) hydroxide (green rust): Formation of $\mathrm{UO}_{2}$ nanoparticles. Environmental Science \& Technology 37: 721-727

Opel K, Weiss S, Hübener S, Zänker H, Bernhard G (2007) Study of the solubility of amorphous and crystalline uranium dioxide by combined spectroscopic methods. Radiochimica Acta 95: 143-149

Payne RB, Casalot L, Rivere T, Terry JH, Larsen L, Giles BJ, Wall JD (2004) Interaction between uranium and the cytochrome c(3) of Desulfovibrio desulfuricans strain G20. Archives of Microbiology 181: 398-406

Rai D, Felmy AR, Ryan JL (1990) Uranium(IV) hydrolysis constants and solubility product of $\mathrm{UO}_{2} \bullet x \mathrm{H}_{2} \mathrm{O}(\mathrm{am})$. Inorganic Chemistry 29: 260-264

Renshaw JC, Butchins LJC, Livens FR, May I, Charnock JM, Lloyd JR (2005) Bioreduction of uranium:
Environmental implications of a pentavalent intermediate. Environmental Science \& Technology 39: 5657-5660

Santos BG, Noël JJ, Shoesmith DW (2005) The effect of $\mathrm{pH}$ on the anodic dissolution of SIMFUEL $\left(\mathrm{UO}_{2}\right)$. Journal of Electroanalytical Chemistry 586: 1-11

Schofield EJ and 11 coauthors (2008) Structure of biogenic uraninite produced by Shewanella oneidensis strain MR-1. Environmental Science \& Technology 42: 7898-7904

Senko JM, Istok JD, Suflita JM, Krumholtz LR (2002) In-situ evidence for uranium immobilization and remobilization. Environmental Science \& Technology 36: 1491-1496

Senko JM, Kelly SD, Dohnalkova AC, McDonough JT, Kemner KM, Burgos WD (2007) The effect of U(VI) bioreduction kinetics on subsequent reoxidation of biogenic U(IV). Geochimica et Cosmochimica Acta 71: 4644-4654

Shoesmith DW (2000) Fuel corrosion processes under waste disposal conditions. Journal of Nuclear Materials 282: 1-31

Singer DM, Farges F, Brown Jr GE (2006) Biogenic $\mathrm{UO}_{2}$ - characterization and surface reactivity. In: Hedman B, Pianetta P (eds) X-Ray Absorption Fine Structure - XAFS13. AIP Conference Proceedings Volume 882, American Institute of Physics, pp 277-279

Suzuki Y, Kelly SD, Kemner KM, Banfield JF (2002) Nanometre-size products of uranium bioreduction. Nature 419: 134

Suzuki Y, Kelly SD, Kemner KM, Banfield JF (2005) Direct microbial reduction and subsequent preservation of uranium in natural near-surface sediment. Applied and Environmental Microbiology 71: 1790-1797

Ulrich K-U, Singh A, Schofield EJ, Bargar JR, Veeramani H, Sharp JO, BernierLatmani R, Giammar DE (2008) Dissolution of biogenic and synthetic $\mathrm{UO}_{2}$ under varied reducing conditions. Environmental Science \& Technology 42: 5600- 5606

Wall JD, Krumholz LR (2006) Uranium reduction. Annual Reviews of Microbiology 60: 149-166

Wu W-M and 26 coauthors (2007) In situ bioreduction of uranium (VI) to submicromolar levels and reoxidation by dissolved oxygen. Environmental Science \& Technology 41: 5716-5723

Yabusaki SB and 10 coauthors (2007) Uranium removal from groundwater via in situ biostimulation: Field-scale modeling of transport and biological processes. Journal of Contaminant Hydrology 93: 216-235 